University of Rhode Island

DigitalCommons@URI

The Rhode Island Current Conditions Index

Economics

7-1-2020

\title{
Rhode Island Current Conditions Index - July 2020
}

Leonard Lardaro

University of Rhode Island, lardaro@uri.edu

Follow this and additional works at: https://digitalcommons.uri.edu/ricci

Part of the Econometrics Commons

Terms of Use

All rights reserved under copyright.

\section{Recommended Citation}

Lardaro, Leonard, "Rhode Island Current Conditions Index -- July 2020" (2020). The Rhode Island Current Conditions Index. Paper 210.

https://digitalcommons.uri.edu/ricci/210

This Newsletter is brought to you for free and open access by the Economics at DigitalCommons@URI. It has been accepted for inclusion in The Rhode Island Current Conditions Index by an authorized administrator of DigitalCommons@URI.For more information, please contact digitalcommons-group@uri.edu. 


\title{
CURRENT CONDITIONS LEONARD LARDARO, URI
}

\author{
Available Online: http: / www.Ilardaro.com/current.htm \\ Twitter: @ladardo
}

VOL XXVIT

NUMBER 8

JULY 2020

Rhode Island's economy turned in a mixed picture in July, as several parts of our economy displayed improvement while others appear to be slipping from levels they recently attained. Our "base" of strong (in relative terms) indicators continues to be Retail Sales, which has held up well given the assistance from the federal government, Private-Service Producing Employment, which reflects non-government, non-goods producing employment (for us, construction and manufacturing), the Manufacturing Wage, which has improved every month since March, and believe it or not, our state's Labor Force (thanks in no small part to the CARES Act). Note that several of these remain well below where they were last July, but their most recent several-month changes appear to be pointing toward strengthening. That's the good news. The bad news is that several of these might ultimately be revised lower with the new labor market data in February or lose their current momentum if the federal government allows the current stalling of national growth to continue. In addition to this, none of these are leading economic indicators. For July none of the leading indicators improved. So, for now, we'll have to settle for what we can get, hoping things improve as the year progresses. This almost makes one wish for the "good old days" when slowing economic activity was recession induced and not the result of a forced stop.

As I have stated over the past several months, I continue to believe that barring a major acceleration in COVID cases here, and we have to keep our fingers crossed about school reopenings, Rhode Island's economy has moved beyond what will prove to be its absolute bottom. The lingering after effects of Rhode Island never adequately adapting its economy to the realities of functioning as a post-manufacturing economy will cause the recovery that ultimately emerges to be more limited in scope than it would have or could have been, a sad testimonial to

\begin{tabular}{|l|r|}
\hline \multicolumn{2}{|c|}{ CCI Indicators - \% Change } \\
\hline Government Employment & -2.9 \\
\hline US Consumer Sentiment & -26.5 \\
\hline Single-Unit Permits & -31.5 \\
\hline Retail Sales & 7.1 \\
\hline Employment Services Jobs & -36.0 \\
\hline Priv. Serv-Prod Employment & -10.1 \\
\hline Total Manufacturing Hours & $-\mathbf{8 . 7}$ \\
\hline Manufacturing Wage & $1.4 \mathrm{Y}$ \\
\hline Labor Force & 0.3 \\
\hline Benefit Exhaustions & 233.3 \\
\hline New Claims & 384.1 \\
\hline Unemployment Rate (change) & 7.6 \\
\hline \multicolumn{2}{|c|}{ Y= Improved Value } \\
\hline
\end{tabular}

the LO of FILO. Another worry I have concerns how Rhode Island's continued mediocre performance resulted in a stagnant population over the years. As the number of COVID deaths here approaches 1,100 , we may ultimately see negative population

\begin{tabular}{|c|c|c|c|c|c|}
\hline \multirow{2}{*}{2019} & $58 \downarrow$ & $50 \uparrow$ & 58 & $50 \downarrow$ \\
\cline { 2 - 6 } & 2020 & 75 & 75 & 33 & 8 \\
\hline
\end{tabular}

growth in 2020, all but assuring that we will lose a congressional seat when those changes are made.

So, what can be said about Rhode Island's economy in July? The good news is that the Current Conditions Index for June was revised higher to 25, which is the July value, as three of the twelve CCI indicators improved on a year-over-year basis. Retail Sales, a strong indicator, grew at a healthy rate in July. Along with this, the Manufacturing Wage, improved for a third consecutive month (don't ask why). Surprisingly, the Labor Force improved in July as well, its first improvement since April.

As has been true of late, the CCI based on monthly changes performed better than the yearly-based CCI. The monthly CCI (see below) was 50 again in July, a neutral value, as half of the indicators improved relative to June. Month-over-month changes, if sustained, will eventually determine how well we do in terms of yearly comparisons. Let's hope the monthly CCI moves above 50 and remains there for some time to come. That will signal the beginning of our move out of this pandemic-induced hardship.

\begin{tabular}{|l|r|}
\hline CCI Indicators - Monthly $\%$ Change \\
\hline Government Employment & 1.0 Y \\
\hline US Consumer Sentiment & -7.6 \\
\hline Single-Unit Permits & -33.2 \\
\hline Retail Sales & $1.3 \mathrm{Y}$ \\
\hline Employment Services Jobs & -0.1 \\
\hline Priv. Serv-Prod Employment & 3.9 Y \\
\hline Total Manufacturing Hours & -2.2 \\
\hline Manufacturing Wage & $1.2 \mathrm{Y}$ \\
\hline Labor Force & 0.9 Y \\
\hline Benefit Exhaustions & 30.9 \\
\hline New Claims & 14.3 \\
\hline Unemployment Rate (change) & $-1.4 \mathrm{Y}$ \\
\hline \multicolumn{2}{|c|}{ Y = Improved Value } \\
\hline
\end{tabular}

\begin{tabular}{|c|c|c|c|c|c|c|c|}
\hline & BOR F & ORCE: & JUL & 2020 & & ak (1) & 2007) \\
\hline Partic & jpatio & Rate & & $.2 \%$ & & $68.6^{\circ}$ & \\
\hline Empl & jymen & Rate & & $.0 \%$ & & 65.40 & \\
\hline & Ec & the & st 1 & & DLT & JULY 2 & 020 \\
\hline $\begin{array}{l}100 \\
90 \\
90\end{array}$ & & & & & $\mathrm{Em}$ & ploym & \\
\hline $\begin{array}{ll}60 \\
60\end{array}$ & & & & & Gai & 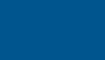 & 600 \\
\hline $3 c$ & & & & & Los & 48 & ,400 \\
\hline & & & & & & & \\
\hline May & Jun & Jul & Aug & Sep & Oct & Nov & Dec \\
\hline $50 \downarrow$ & $58 \downarrow$ & $75 \downarrow$ & 67 & $50 \downarrow$ & $75 \downarrow$ & $58 \downarrow$ & $83 \downarrow$ \\
\hline 8 & $25 \uparrow$ & 25 & & & & & \\
\hline
\end{tabular}

Copyright @ 2018, 2019 Leonard Lardaro, Ph.D. All rights reserved. 